\title{
Myoepithelial Carcinoma of the Nasopharynx: Report of a Rare Case and a Review of the Literature
}

\author{
${\text { Gwyneth } \text { Soon }^{1} \cdot \text { Fredrik Petersson }}^{1}$
}

Received: 17 May 2015/Accepted: 20 June 2015/Published online: 27 June 2015

(C) Springer Science+Business Media New York 2015

\begin{abstract}
Salivary gland carcinomas are very rare in the nasopharynx, with the most frequent histologic types being adenoid cystic carcinoma, mucoepidermoid carcinoma and adenocarcinoma, not otherwise specified. Myoepithelial carcinoma (MECA) is a rare tumor of the salivary glands, and there are only three previously reported cases of nasopharyngeal MECA. The case presented is the fourth reported case of MECA in the nasopharynx. Due to the morphologic heterogeneity of MECA, immunohistochemistry is indispensable in ascertaining the diagnosis. MECA is a locally aggressive tumor, but the long-term prognosis of this tumor in the nasopharynx remains uncertain. In our case the tumor was unresectable and the patient was given chemo-radiotherapy. Despite this, residual tumor was seen on nasoscopy 5 months after initial diagnosis and was documented on a re-biopsy which displayed the same histomorphologic features as the original tumor.
\end{abstract}

Keywords Myoepithelial carcinoma - Nasopharynx · Immunohistochemistry

\section{Introduction}

Salivary gland carcinomas (SGCA) are very rare in the nasopharynx (NP), with a reported incidence of $0.3-0.5 \%$ of all nasopharyngeal cancers $[1,2]$. These carcinomas are

Fredrik Petersson

fredrikpetersson@live.se

1 Department of Pathology, National University Health System, 5 Lower Kent Ridge Road, Singapore 119074, Singapore usually seen in middle-aged men, and the most common histologic types are adenoid cystic carcinoma, mucoepidermoid carcinoma and adenocarcinoma, not otherwise specified (NOS), in descending order of frequency. Some of these carcinomas, especially adenoid cystic carcinoma, may arise in a background of a pleomorphic adenoma (carcinoma ex-pleomorphic adenoma) [3, 4]. Rare cases of polymorphous low grade adenocarcinoma have also been reported [5-7]. SGCAs at this site frequently present at an advanced stage and often with invasion of the base of the skull, involvement of the cranial nerves and sometimes with direct intracranial extension [8].

Myoepithelial carcinoma (MECA) is a rare tumor of salivary glands, the majority of which are seen in the parotid gland. This tumor is known to occur in other unusual locations, such as the breast [9], lung [10], sinonasal tract [11, 12], orbit [13], infratemporal fossa [14], and increasingly, soft tissue sites, where they appear to be characterized by EWSRI gene rearrangements [15]. Interestingly, these gene rearrangements may also be seen in a subset of MECAs with predominantly clear cell features in the salivary gland [16]. MECAs are extremely rare in the $\mathrm{NP}$, with only 3 previously reported cases (one of which was reported in German and not accessible for review) [17-19]. We herein report a 4th case of a patient with nasopharyngeal MECA and review the other two cases in the English literature.

\section{Case Report}

A previously healthy 55 year-old Chinese male with a smoking history of 30-40 pack years presented with epistaxis and nasal obstruction for 6 weeks. On clinical examination, there were no palpable cervical lymph nodes. 
During nasoscopy, a friable mass with contact bleeding in the left NP with extension to the right side was seen (Fig. 1a). Biopsies of the mass were taken. Magnetic resonance imaging (MRI) of the NP and neck showed an exophytic well-circumscribed, lobulated mass bulging into the NP and left nasal cavity from the roof of the nasopharynx and left posterior nasal septum (Fig. 1b, c). The tumor eroded the vomer at its attachment as well as the floor of the sphenoid sinuses. There was also marked widening and extension into both pterygopalatine fossae, bulging of the dura of the middle cranial fossa on the right at the level of the foramen rotundum and marked enlargement of the right foramen rotundum and right vidian canal, in keeping with perineural invasion along the right V2 cranial nerve and vidian nerve, respectively. A post-emission tomography-computed tomography (PETCT) scan showed a $3.2 \times 2.8 \mathrm{~cm}$ FDG-avid lesion corresponding to the tumor seen on MRI, as well as mildly FDG-avid small volume bilateral level II cervical lymph nodes. The tumor was judged to be unresectable and the patient was given chemo-radiotherapy. Despite this, residual tumor was seen on nasoscopy 5 months after initial diagnosis and confirmed on biopsy which showed the same histomorphological features as the original tumor.

\section{Materials and Methods}

The biopsy material composed of five fragments of tissue measuring $0.3-0.6 \mathrm{~cm}$ in maximum diameter; the tissue was fixed in formalin and embedded in paraffin. Four-micron thick sections (from multiple levels) were cut and stained with Hematoxylin and Eosin (H\&E). An immunohistochemical study was performed using commercial antibodies according to the manufacturers' protocols: cytokeratins (AE1/3, CK5/6 and CK7), p53, p63, smooth muscle actin (SMA), S-100 protein, glial fibrillary acidic protein (GFAP), EMA and Ki-67 (Table 1). In situ hybridization for EBV-encoded small RNAs (EBER) was performed with Leica BondMax autostainer using Leica Bond Polymer Detection kit.

\section{Results}

\section{Histomorphology}

The tumor was composed of islands and nests of cells within a prominently myxoid/fibro-myxoid stroma. Occasional pseudoglandular or duct-like luminal spaces were seen. The tumor cells were variably epithelioid to spindled, with some cells containing more abundant eosinophilic cytoplasm imparting a squamoid appearance. The tumor cells showed moderate to severe nuclear pleomorphism. Mitoses and apoptotic bodies were easily identified (Fig. 2a-f).

Table 1 Panel of antibodies used in this study

\begin{tabular}{lllll}
\hline Antigen & Clone & Dilution & $\begin{array}{l}\text { Antigen } \\
\text { retrieval }\end{array}$ & Source \\
\hline AE1/3 & AE1/3 & $1: 100$ & Protease1 $\left(4^{\prime}\right)$ & DAKO \\
CK5/6 & D5/16B4 & $1: 50$ & CC1 $\left(48^{\prime}\right)$ & DAKO \\
CK7 & RN7 & $1: 50$ & CC1 $\left(36^{\prime}\right)$ & Novocastra \\
EMA & E29 & $1: 200$ & CC1 $\left(36^{\prime}\right)$ & DAKO \\
SMA & 1A4 & $1: 1000$ & ER1 $\left(20^{\prime}\right)$ & DAKO \\
S-100 & Polyclonal & $1: 2000$ & No HIER & DAKO \\
P63 & 4A4 & Ready to use & CC1 $\left(64^{\prime}\right)$ & Ventana \\
GFAP & Polyclonal & $1: 3000$ & Protease1 $\left(8^{\prime}\right)$ & DAKO \\
P53 & DO-7 & $1: 100$ & CC1 $\left(64^{\prime}\right)$ & DAKO \\
Ki-67 & MIB-1 & $1: 100$ & CC1 $\left(36^{\prime}\right)$ & DAKO \\
\hline
\end{tabular}

CC1 Cell conditioning solution $\mathrm{pH6}$
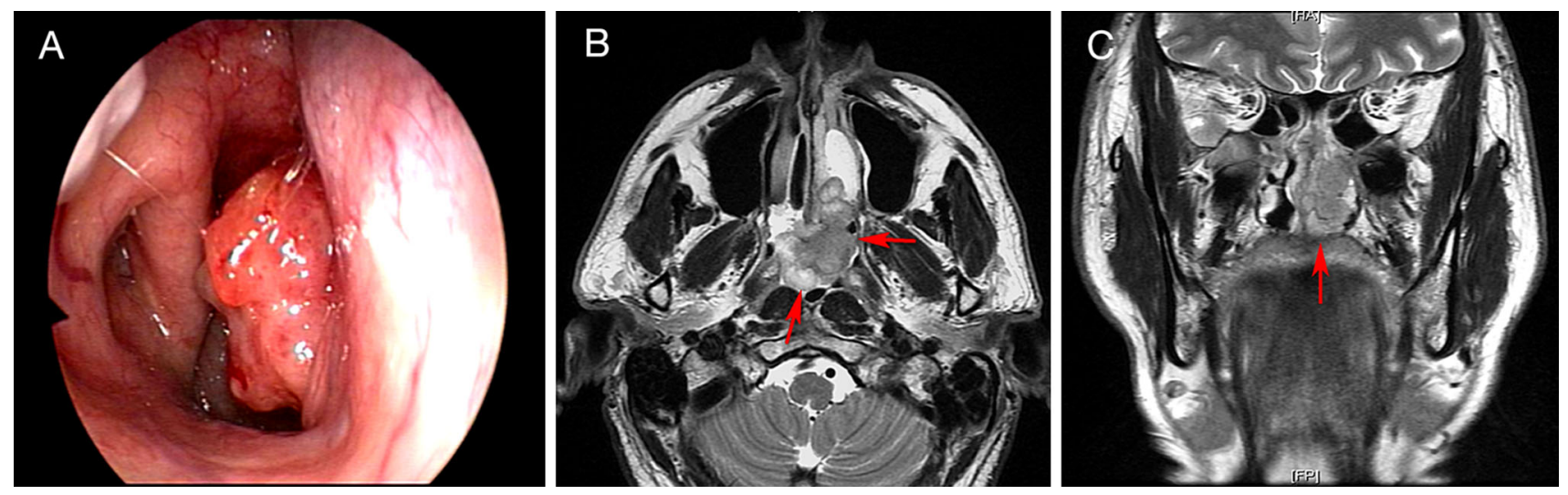

Fig. 1 Clinical and radiologic findings. a Nasoscopic image of a friable mass in the left post-nasal space. b, c MRI image (axial and coronal plane) of a locally advanced tumor in the left nasopharynx (arrows) 

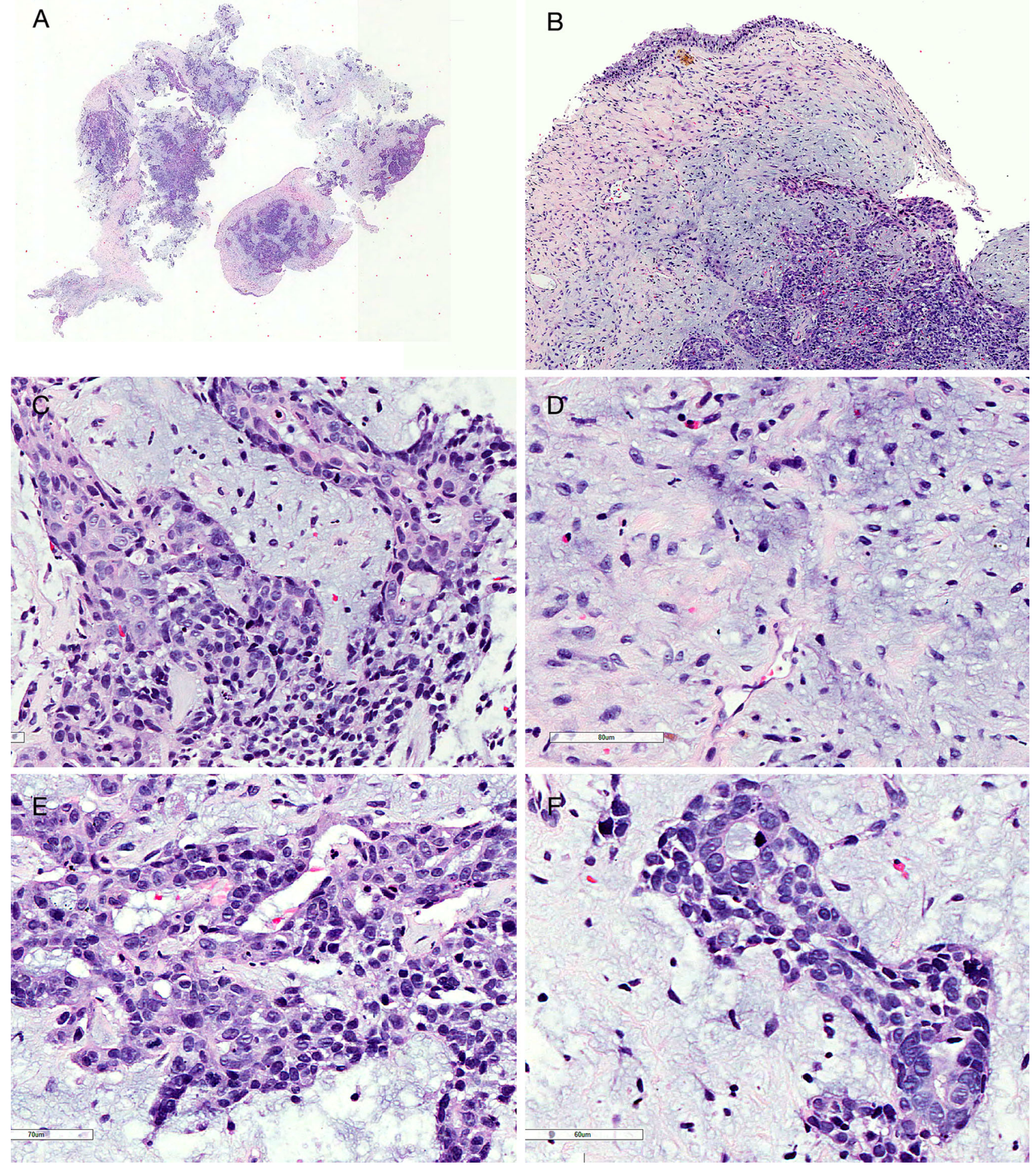

Fig. 2 Routine morphology. a Whole mount view of the biopsy fragments $(H \& E$, original magnification $\times 20)$. b Trabeculae of cells in a basophilic myxoid stroma. The overlying native epithelium is unaffected $(\times 100)$. c Epithelioid tumor cells, some with a squamoid

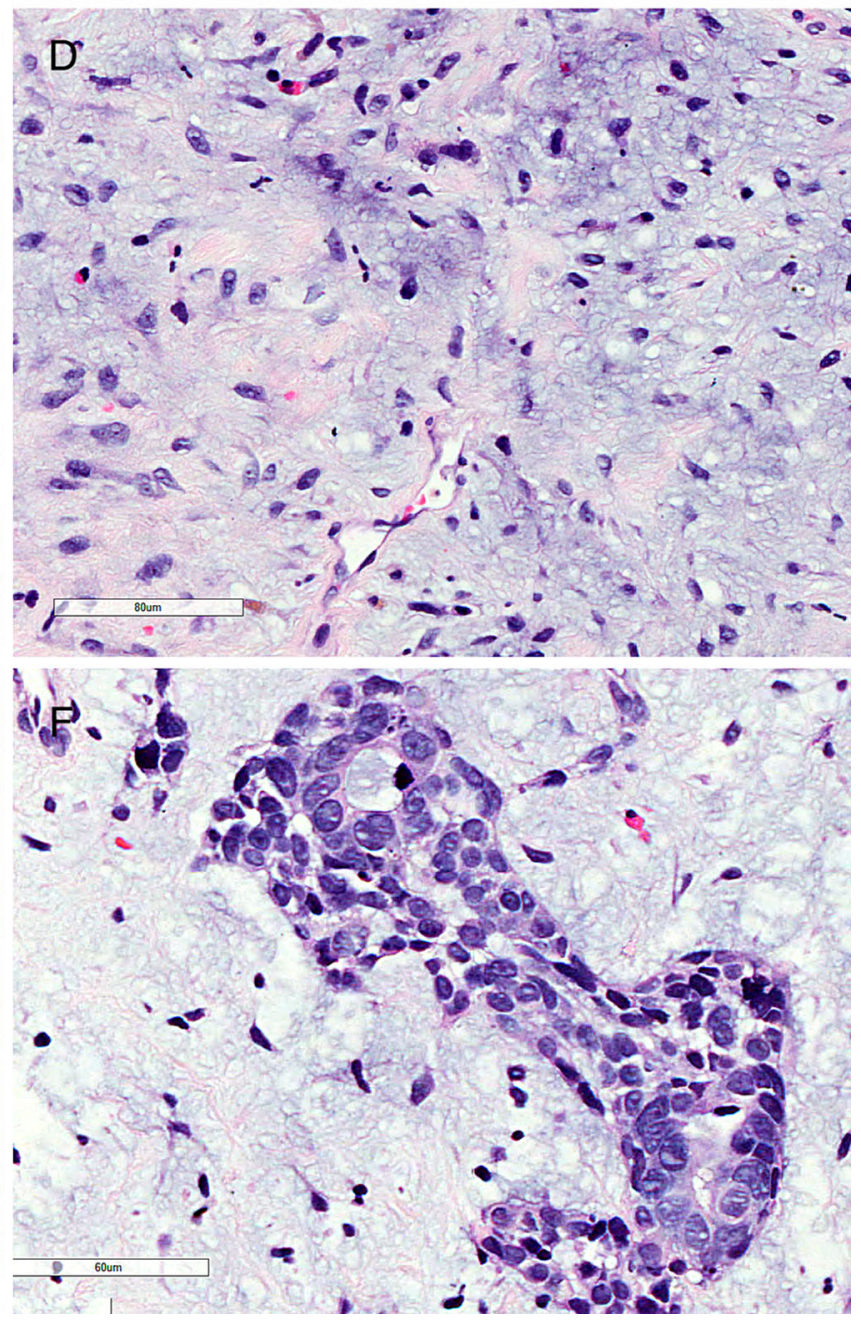

appearance $(\times 150)$. d Spindled cells embedded in a myxoid stroma $(\times 150)$. e Tumor cells with obvious nuclear pleomorphism and conspicuous apoptotic and mitotic figures $(\times 200)$. f Pseudoglandular structures with secretions $(\times 400)$ 

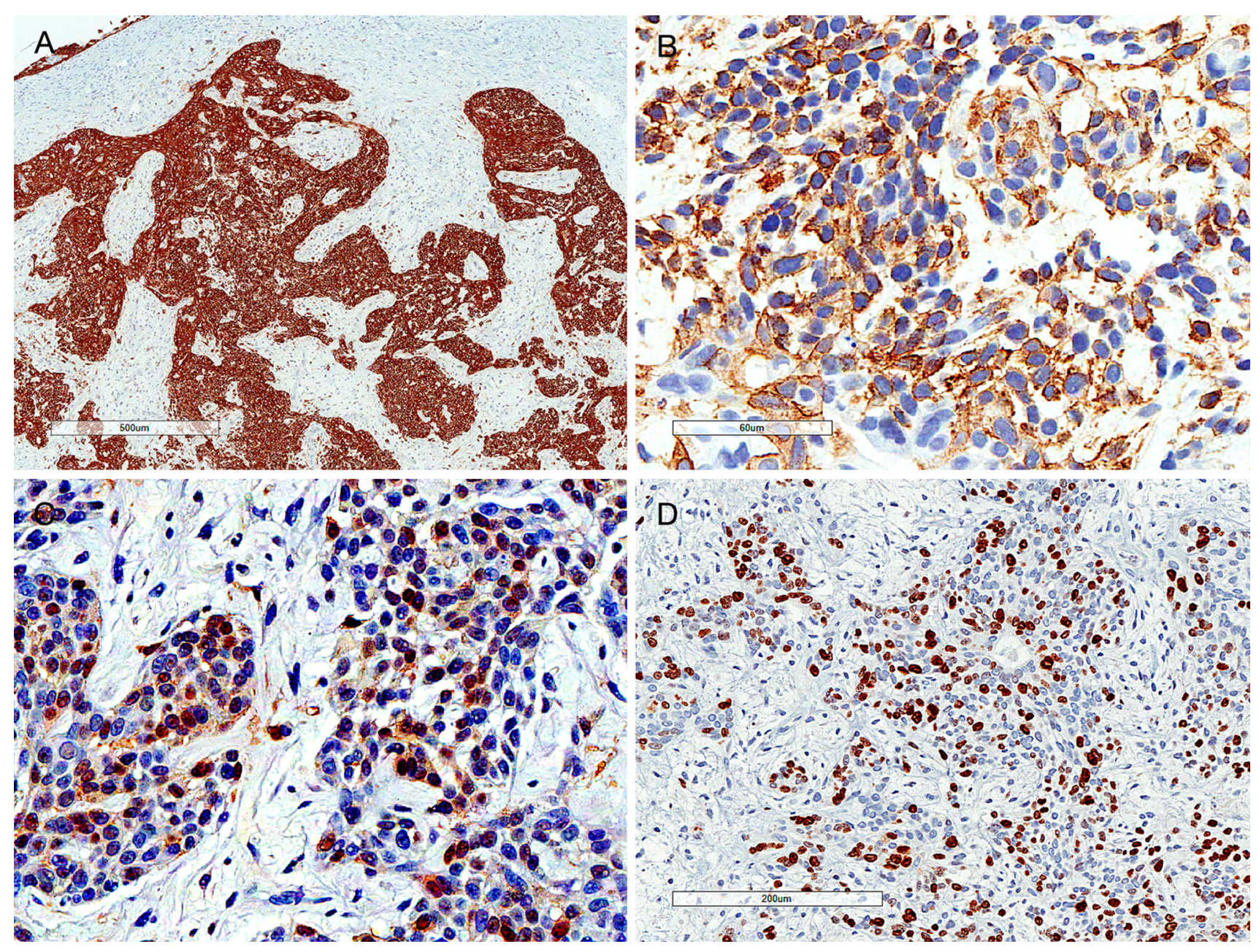

Fig. 3 Immunohistochemical findings. a, b Tumor cells displaying strong diffuse staining with a CK 5/6 (original magnification $\times 100$ ) and b SMA $(\times 400)$. c Focal weak expression of S-100 protein $(\times 400)$. d Proliferative index $($ Ki-67) approximately $30-40 \%(\times 200)$

\section{Immunohistochemistry}

The tumor cells showed strong diffuse positive expression of cytokeratins AE1/3, CK5/6 and CK7, as well as SMA. There was focal weak expression of S-100 protein, and patchy membranous expression of EMA. Scattered tumor cells showed positive nuclear expression of $\mathrm{p} 53$. There was no significant expression of p63 or GFAP. No nuclear positivity for EBV by ISH was present. The proliferative index (Ki-67) was approximately 30-40 \% (Fig. 3a-d).

\section{Discussion}

We herein present, to the best of our knowledge, the third case of nasopharyngeal MECA in the English literature. Myoepithelial cells are functionally and phenotypically complex, which has led to difficulties in the recognition and classification of myoepithelial-rich neoplasms. Several review papers, including those by Barnes et al. [20] and Dardick et al. [21-24], helpfully defined many of the cytomorphologic, immunophenotypic and ultrastructural characteristics of myoepithelial salivary gland neoplasms. The resulting consensus was that myoepithelioma constituted a distinct lesion within the spectrum of salivary adenomas that spans monomorphic adenomas and myoepitheliomas at the ends, and pleomorphic adenoma in the middle. The corollary to this resulted in the addition of myoepithelial carcinoma as a separate entity to the 2nd edition of the WHO histological classification of salivary gland tumors [25].

Myoepithelial carcinoma (MECAs) characteristically have a multilobulated architecture, and display solid, trabecular and/or reticular patterns, with a variably prominent myxoid and/or hyaline stroma. The basophilic myxoid matrix is composed of predominantly chondroitin sulfate proteoglycans, while the eosinophilic hyaline component represents basement membrane-related elements [26]. The 
fact that neoplastic myoepithelial cells are secretory is a useful clue to the diagnosis. In addition, a hallmark of neoplastic myoepithelial cells is its morphologic heterogeneity. The morphologic cell types include spindled, stellate, epithelioid, plasmacytoid (hyaline), or occasionally vacuolated with signet ring like appearance, which often blend imperceptibly into one another within the same tumor [27]. Various metaplastic phenomena, including squamous, chondroid and sebaceous differentiation may be seen, with squamous metaplasia being the most common [27].

From a differential diagnostic point, it is important to be aware that approximately $10 \%$ of non-keratinizing nasopharyngeal carcinomas (NPCs) have an uncommon morphology such as spindle and clear cells; a rare case of reticular and myxoid non-keratinizing NPC mimicking a salivary gland carcinoma has recently been reported [28]. Negative expression of myoepithelial markers such as GFAP, calponin and S-100, and positive expression for EBER-ISH in the neoplastic cells would lead to the appropriate diagnosis of NPC. Sclerosing rhabdomyosarcoma is a recently described variant of adult rhabdomyosarcoma that may also show a marked resemblance to MECAs, including oval to spindled cells in a hyalinized/chondroid matrix. This tumor has a predilection for the head and neck region, and has been reported in the parotid gland [29, 30]. While sclerosing rhabdomyosarcoma has not yet been described in the nasopharynx, spindle cell rhabdomyosarcoma, a related entity, may rarely occur in the nasopharynx [31]. The proportion of myoid cells in these two entities is variable, and a high index of suspicion is needed to prompt further immunohistochemical work-up for accurate diagnosis, of which desmin and myogenin are essential.

Neoplastic myoepithelial cells may vary significantly in their immunohistochemical protein expression profile(s) and there is no universal agreement on what constitutes a "myoepithelial defining immunophenotype". The
WHO has proposed reactivity for cytokeratins and at least one other myoepithelial marker such as SMA, GFAP and calponin to definitively diagnose myoepithelial carcinoma [32-34]. In a study of 25 cases of myoepithelial carcinomas of the salivary glands, S-100 protein was purported to be a sensitive (though not specific) marker of neoplastic myoepithelial cells (18/18 of tumors showed positive expression) [27]. Calponin has recently been noted to be a highly specific and fairly sensitive marker of myoepithelial differentiation [35, 36].

As the current definitive diagnosis of MECAs relies heavily on the immunohistochemical profile of the neoplastic cells, a comprehensive panel of myoepithelial and epithelial markers should be performed. This is especially so in tumors with pseudoglands or duct-like lumina, where demonstration of non-luminal/myoepithelial cell differentiation of the lining cells would argue against a diagnosis of adenocarcinoma (a pertinent differential diagnosis if the accompanying myxoid stroma is misconstrued as epithelial mucin), as well as epithelial-myoepithelial carcinoma (which may exhibit areas of myoepithelial overgrowth and has also been reported in the nasopharynx [37]). The consensus thus far has been that a tumor containing more than the occasional true luminal cell should not be included in the category of myoepithelial neoplasia [8]. The presence of luminal cells may be demonstrated by carcinoembryonic antigen (CEA) and EMA. Although neoplastic myoepithelial cells may show membranous staining with EMA, apical staining of the cells at the gland-luminal surface would suggest ductal cell differentiation [38]. CK7 is a less discriminatory marker, as immunoreactivity is strongest within luminal ductal cells, but may also be seen within basal, myoepithelial and acinar cells [39]. In our case, the same population of neoplastic cells exhibited expression of both CK5/6 and CK7 rather than defining two separate neoplastic cell populations. In addition, our case demonstrated strong reactivity of the tumor cells with SMA and focally, S-100, thus fulfilling the WHO criteria of a myoepithelial tumor.

Table 2 Summary of cases of myoepithelial carcinoma in the nasopharynx reported in the English literature

\begin{tabular}{|c|c|c|c|c|c|c|}
\hline Case report & Age & Gender & Presenting history & Size & Treatment & Outcome \\
\hline Current case & 55 & Male & Nasal obstruction, epistaxis & $3.2 \mathrm{~cm}$ & CT, RT & $\begin{array}{l}5 \text { months; residual } \\
\text { tumor }\end{array}$ \\
\hline Dhawan et al. [19] & 60 & Female & $\begin{array}{l}\text { Nasal blockage, hyponasal speech, } \\
\text { conductive hearing loss and ear } \\
\text { fullness }\end{array}$ & $4.3 \mathrm{~cm}$ & $\begin{array}{l}\text { Surgery, } \\
\text { RT }\end{array}$ & $\begin{array}{l}28 \text { months; no } \\
\text { recurrence }\end{array}$ \\
\hline Tuncel et al. [18] & 60 & Female & $\begin{array}{l}\text { Nasal obstruction and intermittent } \\
\text { epistaxis for } 4 \text { years. Recurrence } \\
\text { in 14th month with intracranial } \\
\text { extension and pulmonary } \\
\text { metastases }\end{array}$ & $\begin{array}{l}\text { Biopsy specimen } \\
\text { measuring } 5 \mathrm{~cm}\end{array}$ & $\begin{array}{l}\text { Surgery, } \\
\text { RT, CT }\end{array}$ & $\begin{array}{l}\text { Intracranial extension } \\
\text { and pulmonary } \\
\text { metastases. Died of } \\
\text { disease } 4 \text { weeks later }\end{array}$ \\
\hline
\end{tabular}

$R T$ radiotherapy, $C T$ chemotherapy 
MECA may arise de novo, but it is believed that up to $50 \%$ of MECAs develop in pre-existing pleomorphic adenoma or from myoepitheliomas, particularly in recurrences [27, 32, 33]. There have been few case reports of benign myoepitheliomas in the sinonasal tract [40, 41], one of which occurred in the nasopharynx [42]. Cases of pleomorphic adenoma in the nasopharynx, though rare, have been reported slightly more frequently [43-45]. It is believed that myoepithelial carcinomas were diagnosed as mixed malignant tumor/carcinoma ex-pleomorphic adenoma in the past, likely leading to under-recognition of this entity [27]. In our case, there was no evidence of a benign precursor lesion, although admittedly, our case was only sampled with limited biopsies. In comparison to benign myoepitheliomas, myoepithelial carcinomas most commonly demonstrate increased high mitotic activity and some degree of nuclear pleomorphism. It has been suggested that increased mitotic activity is a helpful indicator of malignancy, especially in small biopsies [27]. In line with this, it has been proposed that more than seven mitotic figures per ten high-power fields or a Ki-67 labeling index of more than $10 \%$ is highly suggestive of myoepithelial carcinoma [32]. However, it should be noted that at the low-grade end of the spectrum of MECAs, there is overlap with myoepitheliomas both in morphology and with the proliferative activity. In such cases, demonstration of unequivocal evidence of infiltrative growth is the sine qua non in establishing a diagnosis of malignancy [8].

Myoepithelial carcinomas in salivary glands are locally aggressive tumors that exhibit variable clinical outcomesa third die of disease, a third have recurrences (mostly multiple) and the rest remain disease free. Marked cellular pleomorphism and high proliferative activity appear to correlate with a poor clinical outcome [27, 32], although cases with similar histologic features have been reported to have an indolent course [33]. There appears to be no difference in the clinical behaviour of "de novo" myoepithelial carcinomas and of those arising in pleomorphic adenomas or in benign myoepitheliomas [8]. Due to the rarity of myoepithelial carcinomas in the nasopharynx, the outcome and optimum management of these tumors in this location remains uncertain (Table 2). It has been reported that salivary gland-type nasopharyngeal carcinomas have a comparable to better prognosis compared with non-keratinizing and keratinizing squamous cell carcinoma of the nasopharynx [46]. The same study also demonstrated that the presence of cervical lymph node metastases was a significant factor affecting disease free survival, and other authors have suggested that elective neck dissection is indicated in the management of nasopharyngeal salivary gland malignancies [47]. Regardless of histologic type, carcinomas in the nasopharynx likely have an increased risk of intracranial extension by virtue of their location, thereby complicating surgical removal and probably resulting in higher subsequent morbidity and mortality.

In conclusion, to the best of our knowledge, we report the 3rd case in the English literature of myoepithelial carcinoma arising in the nasopharynx. The morphologic heterogeneity of these tumors requires supportive immunohistochemical studies to aid diagnosis, especially for tumors in unusual locations. Greater awareness of the occurrence of myoepithelial carcinomas in the nasopharynx may lead to increased recognition of this unusual entity, with subsequent improved understanding of best clinical management and outcomes.

\section{Compliance with Ethical Standards}

Conflict of interest The authors declare that they have no conflict of interest.

\section{References}

1. He JH, Zong YS, Luo RZ, Liang XM, Wu QL, Liang YJ. Clinicopathological characteristics of primary nasopharyngeal adenocarcinoma. Ai Zheng. 2003;22:753-7.

2. Liu S, Ow A, Ruan M, Yang W, Zhang C, Wang L, Zhang C. Prognostic factors in primary salivary gland mucoepidermoid carcinoma: an analysis of 376 cases in an Eastern Chinese population. Int J Oral Maxillofac Surg. 2014;43:667-73.

3. Cimino-Mathews A, Lin BM, Chang SS, Boahene KD, Bishop JA. Carcinoma ex pleomorphic adenoma of the nasal cavity. Head Neck Pathol. 2011;5:405-9.

4. Toluie S, Thompson LD. Sinonasal tract adenoid cystic carcinoma ex-pleomorphic adenoma: a clinicopathologic and immunophenotypic study of 9 cases combined with a comprehensive review of the literature. Head Neck Pathol. 2012;6: 409-21.

5. Wenig BM, Harpaz N, DelBridge C. Polymorphous low-grade adenocarcinoma of seromucous glands of the nasopharynx. A report of a case and a discussion of the morphologic and immunohistochemical features. Am J Clin Pathol. 1989;92: 104-9.

6. Wei YC, Huang CC, Chien CY, Hwang JC, Chen WJ. Polymorphous low-grade adenocarcinoma of the nasopharynx: a case report and brief review. J Clin Pathol. 2008;61:1124-6.

7. Lengyel E, Somogyi A, Godeny M, Szerdahelyi A, Nemeth G. Polymorphous low-grade adenocarcinoma of the nasopharynx. Case report and review of the literature. Strahlenther Onkol. 2000;176:40-2.

8. Kuo TT, Chan JKC, Wenig BM, Eveson JW. Nasopharyngeal papillary adenocarcinoma and salivary gland-type carcinomas. In: Barnes L, Eveson JW, Reichart P, Sidransky D, editors. WHO classification of tumours. Lyon: IARC Press; 2005. p. 98.

9. Tavassoli FA. Myoepithelial lesions of the breast. Myoepitheliosis, adenomyoepithelioma, and myoepithelial carcinoma. Am J Surg Pathol. 1991;15:554-68.

10. Masuya D, Haba R, Huang CL, Yokomise H. Myoepithelial carcinoma of the lung. Eur J Cardiothorac Surg. 2005;28:775-7.

11. Graadt van Roggen JF, Baatenberg-de Jong RJ, Verschuur HP, Balhuizen JC, Slootweg PJ, van Krieken JH. Myoepithelial carcinoma (malignant myoepithelioma): first report of an occurrence in the maxillary sinus. Histopathology. 1998;32:239-41.

12. Petersson F, Chao SS, Ng SB. Anaplastic myoepithelial carcinoma of the sinonasal tract: an underrecognized salivary-type 
tumor among the sinonasal small round blue cell malignancies? Report of one case and a review of the literature. Head Neck Pathol. 2011;5:144-53.

13. Tran TL, Broholm H, Daugaard S, Fugleholm K, Poulsgaard L, Prause JU, Kennedy SM, Heegaard S. Myoepithelial carcinoma of the orbit: a clinicopathological and histopathological study. APMIS. 2010;118:324-30.

14. Ghosh A, Saha S, Saha VP, Sadhu A, Chattopadhyay S. Infratemporal fossa myoepithelial carcinoma-a rare case report. Oral Maxillofac Surg. 2009;13:59-62.

15. Jo VY, Fletcher CD. Myoepithelial neoplasms of soft tissue: an updated review of the clinicopathologic, immunophenotypic, and genetic features. Head Neck Pathol. 2015;9:32-8.

16. Skalova A, Weinreb I, Hyrcza M, Simpson RH, Laco J, Agaimy A, Vazmitel M, Majewska H, Vanecek T, Talarcik P, Manajlovic S, Losito SN, Steiner P, Klimkova A, Michal M. Clear cell myoepithelial carcinoma of salivary glands showing EWSR1 rearrangement: molecular analysis of 94 salivary gland carcinomas with prominent clear cell component. Am J Surg Pathol. 2015;39:338-48.

17. Nilles R, Lenarz T, Kaiserling E. Myoepithelial carcinoma of the nasopharynx. Case report and review of the literature. HNO. 1993;41:396-400.

18. Tuncel U, Ergul G, Ozlugedik S, Unal A. Myoepithelial carcinoma in the nasopharynx: an unusual localization. Yonsei Med J. 2004;45:161-5.

19. Dhawan A, Shenoy A, Sriprakash D. Myoepithelial carcinoma of the nasopharynx: case report of a rare entity. Natl J Maxillofac Surg. 2011;2:207-9.

20. Barnes L, Appel BN, Perez H, El-Attar AM. Myoepithelioma of the head and neck: case report and review. J Surg Oncol. $1985 ; 28: 21-8$.

21. Dardick I, Thomas MJ, van Nostrand AW. Myoepitheliomanew concepts of histology and classification: a light and electron microscopic study. Ultrastruct Pathol. 1989;13:187-224.

22. Dardick I. Myoepithelioma: definitions and diagnostic criteria. Ultrastruct Pathol. 1995;19:335-45.

23. Dardick I, Cavell S, Boivin M, Hoppe D, Parks WR, Stinson J, Yamada S, Burns BF. Salivary gland myoepithelioma variants. Histological, ultrastructural, and immunocytological features. Virchows Arch A Pathol Anat Histopathol. 1989;416:25-42.

24. Dardick I, van Nostrand AW. Myoepithelial cells in salivary gland tumors-revisited. Head Neck Surg. 1985;7:395-408.

25. Seifert G, Sobin LH. The world health organization's histological classification of salivary gland tumors. A commentary on the second edition. Cancer. 1992;70:379-85.

26. Sternlicht MD, Safarians S, Rivera SP, Barsky SH. Characterizations of the extracellular matrix and proteinase inhibitor content of human myoepithelial tumors. Lab Invest. 1996;74:781-96.

27. Savera AT, Sloman A, Huvos AG, Klimstra DS. Myoepithelial carcinoma of the salivary glands: a clinicopathologic study of 25 patients. Am J Surg Pathol. 2000;24:761-74.

28. Petersson F, Vijayadwaja D, Loh KS, Tan KB. Reticular and myxoid non-keratinizing nasopharyngeal carcinoma: an unusual case mimicking a salivary gland carcinoma. Head Neck Pathol. 2014;8:364-8.

29. Lamovec J, Volavsek M. Sclerosing rhabdomyosarcoma of the parotid gland in an adult. Ann Diagn Pathol. 2009;13:334-8.

30. Warner BM, Griffith CC, Taylor WD, Seethala RR. Sclerosing rhabdomyosarcoma: presentation of a rare sarcoma mimicking myoepithelial carcinoma of the parotid gland and review of the literature. Head Neck Pathol. 2015;9:147-52.

31. Nascimento AF, Fletcher CD. Spindle cell rhabdomyosarcoma in adults. Am J Surg Pathol. 2005;29:1106-13.

32. Nagao T, Sugano I, Ishida Y, Tajima Y, Matsuzaki O, Konno A, Kondo Y, Nagao K. Salivary gland malignant myoepithelioma: a clinicopathologic and immunohistochemical study of ten cases. Cancer. 1998;83:1292-9.

33. Di Palma S, Guzzo M. Malignant myoepithelioma of salivary glands: clinicopathological features of ten cases. Virchows Arch A Pathol Anat Histopathol. 1993;423:389-96.

34. Skalova A, Jakel KT. Myoepithelial carcinoma. In: Barnes L, Eveson JW, Reichart P, Sidransky D, editors. WHO classification of tumours. Lyon: IARC Press; 2005. p. 240-1.

35. Savera AT, Gown AM, Zarbo RJ. Immunolocalization of three novel smooth muscle-specific proteins in salivary gland pleomorphic adenoma: assessment of the morphogenetic role of myoepithelium. Mod Pathol. 1997;10:1093-100.

36. Kane SV, Bagwan IN. Myoepithelial carcinoma of the salivary glands: a clinicopathologic study of 51 cases in a tertiary cancer center. Arch Otolaryngol Head Neck Surg. 2010;136:702-12.

37. Imate Y, Yamashita H, Endo S, Okami K, Kamada T, Takahashi M, Kawano H. Epithelial-myoepithelial carcinoma of the nasopharynx. ORL J Otorhinolaryngol Relat Spec. 2000;62:282-5.

38. Nagao T, Sato E, Inoue R, Oshiro H, HTakahashi R, Nagai T, Yoshida M, Suzuki F, Obikane H, Yamashina M, Matsubayashi J. Immunohistochemical analysis of salivary gland tumors: application for surgical pathology practice. Acta Histochem Cytochem. 2012;45:269-82.

39. Meer S, Altini M. CK7+/CK20- immunoexpression profile is typical of salivary gland neoplasia. Histopathology. 2007;51: 26-32.

40. Begin LR, Black MJ. Salivary-type myxoid myoepithelioma of the sinonasal tract: a potential diagnostic pitfall. Histopathology. 1993;23:283-5.

41. Lateef SS, Castillo M, Mukherji SK, Cooper LL. Myoepithelioma of the nasal piriform aperture: CT findings. AJR Am J Roentgenol. 1999;173:1413-4.

42. Gaio E, Perasole A, Bagatella F. Bilateral myoepithelioma of the nasopharynx: a case report. Auris Nasus Larynx. 2009;36: 496-500.

43. Maruyama A, Tsunoda A, Takahashi M, Kishimoto S, Suzuki M. Nasopharyngeal pleomorphic adenoma presenting as otitis media with effusion: case report and literature review. Am J Otolaryngol. 2014;35:73-6.

44. Martinez-Capoccioni G, Martin-Martin C, Espinosa-Restrepo F. Transnasal endoscopic resection of a nasopharyngeal pleomorphic adenoma: a rare case report. Eur Arch Otorhinolaryngol. 2012;269:2009-13.

45. Berrettini S, Fortunato S, De Vito A, Bruschini L. A rare case of nasopharyngeal pleomorphic adenoma. Case Rep Otolaryngol. 2013;2013:712873.

46. Cao CN, Zhang XM, Luo JW, Xu GZ, Gao L, Li SY, Xiao JP, Yi JL, Huang XD, Liu SY, Xu ZG, Tang PZ. Primary salivary glandtype carcinomas of the nasopharynx: prognostic factors and outcome. Int J Oral Maxillofac Surg. 2012;41:958-64.

47. Schramm VL Jr, Imola MJ. Management of nasopharyngeal salivary gland malignancy. Laryngoscope. 2001;111:1533-44. 